\title{
Statement OF THE MAX PlanCK InSTITUTe FOR InTElleCtual Property, Competition and TAX LAW ON THE REVIEW OF EU LEGISLATION ON CUSTOMS ENFORCEMENT OF Intellectual Property Rights ${ }^{1}$
}

\author{
THOMAS JAEGER
}

HENNING GROSSE RUSE - KHAN

JOSEF DREXL

RETO M. HILTY

\section{CONTEXT}

1. Over the last decade, the Commission and Council have significantly increased their efforts for international enforcement of intellectual property (IP) rights. The measures and fields of action here range from the tight monitoring of the TRIPScompliance of trade partners $^{2}$ to a negotiation of new bi- or multilateral agreements incorporating TRIPS-plus standards (e.g. the various ongoing rounds of negotiating free trade agreements (FTAs) ${ }^{3}$ or the ongoing consultations over ACTA $)^{4}$ and fur-

\footnotetext{
${ }^{1}$ See Council Regulation (EC) No 1383/2003 of 22 July 2003 concerning customs action against goods suspected of infringing certain intellectual property rights and the measures to be taken against goods found to have infringed such rights ("Border Measures Regulation", "BMR"), [2003] OJ L $196 / 7$.

${ }^{2}$ See EC Commission - DG Trade, Strategy for the Enforcement of Intellectual Property Rights in Third Countries, online available at http://trade.ec.europa.eu/doclib/docs/2005/april/tradoc_122636.pdf. This strategy aims to set "the guidelines for the European Commission towards a reduction of the level of IPR violations taking place beyond the EU borders, worldwide" and inter alia relies on identifying "priority countries": EC action shall focus on the "most problematic countries in terms of IPR violations" - including source countries, transit countries and target countries.

${ }^{3}$ For an overview of the EU's existing bilateral agreements (including Association Agreements (AAs) and Economic Partnership Agreements (EPAs)) and ongoing negotiations see http://ec.europa.eu/trade/creating-opportunities/bilateral-relations/
} 
ther initiatives within the WTO, the G8 and the OECD to complement the TRIPSstandard with a number of flanking and soft-policy measures such as enhanced political dialogue, provision of incentives, training and technical cooperation, awareness raising, exchange of best-practice and institutional cooperation. ${ }^{5}$ Likewise, the involvement of rightholders (and their representatives) in international IP enforcement is strengthened beyond the existing complaints mechanism under the so-called Trade Barriers Regulation ${ }^{6}$ to include specially trained private operators in border enforcement in particular. ${ }^{7}$ Finally, the Commission envisages placing certain notorious IP infringing states on a blacklist entailing, in particular, the building of international "alliances" against them. ${ }^{8}$

2. This impressive catalogue of measures is designed to tackle 'fully foreign' IP infringements, i.e. where the place of protection lies outside the EU and where the infringing acts are fully confined to non-EU jurisdictions. By contrast, enforcement action against products destined for the EU market and infringing IP rights protected within the EU can be taken on the basis of internal EU legislation ${ }^{9}$ when those products enter EU territory.

3. Located in between the external and internal dimensions of IP enforcement is the drive by stakeholders to act against goods in transit in the context of border procedures. Starting in 2008, Dutch authorities in particular have delayed and returned several shipments of generic drugs transiting EU ports on account of suspected pat-

\footnotetext{
${ }^{4}$ An official draft of the long secret ACTA negotiation text has been made available in April 2010: See Anti-Counterfeiting Trade Agreement, Consolidated Text Prepared for Public Release, April 2010 - available at http://trade.ec.europa.eu/doclib/docs/2010/april/tradoc_146029.pdf.

${ }^{5}$ Cf. Strategy for the Enforcement of Intellectual Property Rights in Third Countries, Commission position paper and annex of 10 November 2004, 5 et seq., available at http://trade.ec.europa.eu/doclib/docs/2005/april/tradoc_122636.pdf

${ }^{6}$ Council Regulation (EC) No. 3286/94 of 22 December 1994 laying down Community procedures in the field of the common commercial policy in order to ensure the exercise of the Community's rights under international trade rules, in particular those established under the auspices of the World Trade Organization ('TBR'), [1994] OJ L 349/71; cf. also Enforcement Strategy (fn. 5), 10 et seq.

${ }^{7}$ Cf. Enforcement Strategy (fn. 5), 11.

${ }^{8}$ Enforcement Strategy (fn. 5), 4.

${ }^{9}$ Cf. particularly Directive 2004/48/EC of the European Parliament and of the Council of 29 April 2004 on the enforcement of intellectual property rights,[2004] OJ L 157/45.
} 
ent infringements. ${ }^{10}$ The shipments predominantly originated in India and were all destined to developing countries such as Brazil, Venezuela, Colombia, Peru or Nigeria. ${ }^{11}$ The drugs at issue were protected in the EU, but apparently not in the countries of origin or destination. The legal basis for those actions was provided by the EU's Border Measures Regulation (BMR), ${ }^{12}$ which is now under review by the Commission and currently open to public consultation.

4. Against this background, the Max Planck Institute for Intellectual Property, Competition and Tax Law participates in the consultations over the BMR to assess a number of core questions of IP enforcement in the international context:

a. Should the scope of application of the BMR include goods in transit?

b. Should the types and availability of border measures differ according to the type of right concerned?

c. Does the WTO framework, especially in form of TRIPS, contain relevant obligations which the EU must take into account when reviewing the scope of its border measures regime?

Those questions are subsequently discussed individually and complemented by a summary of proposals for the coming amendment of the BMR.

\section{CUSTOMS ACTION OVER GOODS IN TRANSIT}

5. The question of jurisdiction over goods transiting the EU may be approached from three perspectives, looking at the general role of the territoriality principle in IP en-

\footnotetext{
${ }^{10}$ For a detailed discussion on the consistency of such seizures with EU and WTO law see Henning Grosse Ruse - Khan \& Thomas Jaeger, 'Policing Patents Worldwide? EC Border Measures against Transiting Generic Drugs under EC- and WTO Intellectual Property Regimes', (2009) 40 International Review of Intellectual Property and Competition Law (IIC) 502.

11 See Reuters, Brazil to Object Seizure of Generic Drug, 23 January 2009, online available at http://www.reuters.com/article/marketsNews/idUSN2327254420090123 (accessed 22 April 2009); ICTSD, Dutch Seizure of Generic Drugs Sparks Controversy, Bridges News Vol.13 No.3, online available at http://ictsd.net/i/news/bridgesweekly/38841/ (accessed 22 April 2009); IP Watch, Alarm Escalates Over Delayed Generic Drug Shipments As Action Sought, 6 March 2009, online available at http://www.ip-watch.org/weblog/2009/03/06/alarm-escalates-over-delayed-generic-drugshipments-as-action-sought/ (accessed 22 April 2009).

${ }^{12}$ Cf. fn. 1.
} 
forcement, the rules set by the international framework for IP enforcement and the current approach of the BMR respectively.

\section{TERRITORIALITY AND LEGAL INTEGRATION}

6. Territoriality is commonly recognized as a guiding principle in relation to IP rights protection. ${ }^{13}$ Under the principle of territoriality, IP rights enjoy protection only in the territory for which they have been acquired or granted. IP protection results not from international agreements such as TRIPS but from a bundle of national laws implementing these agreements. ${ }^{14}$ The existence and scope of protection therefore depends on the domestic law and is in general limited to the domestic territory. Under that traditional construction of territoriality, the law of the country of protection also governs the validity of the IP right, the definition of infringements and the claims resulting from infringements. As part of the national definition of the concept of infringement, the question of whether there is jurisdiction over goods in transit is therefore also principally determined by national law.

\footnotetext{
${ }^{13}$ Cf., e.g., Case C-3/91 Exportur [1992] ECR I-5529, para. 12; Case 9/93 IHT [1994] ECR I-2789, para. 22; Case T-291/03 Consorzio per la tutela del formaggio Grana Padano [2007] ECR II-3081, para. 80; Joined Cases T-57/04 and T-71/04 Anheuser Busch [2007] ECR II-1829, para. 202; Art. 8 Regulation (EC) No. 864/2007 of the European Parliament and of the Council of 11 July 2007 on the law applicable to non-contractual obligations (Rome II Regulation), [2007] OJ L 199/40; Art. 22(4) Council Regulation (EC) No. 44/2001 of 22 December 2000 on jurisdiction and the recognition and enforcement of judgments in civil and commercial matters (Brussels Regulation), [2001] OJ L 12/1; also Karl-Friedrich Beier, Territoriality of Trademark Law and International Trade, (1970) 21 IIC 48, at 48 et seq.; Cohen Jehoram, 'International Exhaustion versus Importation Right: a Murky Area of Intellectual Property Law', (1996) GRUR 280, at 281; Lydia Lundstedt, 'Jurisdiction and the Principle of Territoriality in Intellectual Property Law: Has the Pendulum Swung Too Far in the Other Direction?, (2001) 32 IIC 124, at 124 et seq.; Alexander von Mühlendahl \& Dieter Stauder, 'Territorial Intellectual Property Rights in a Global Economy - Transit and Other "Free Zones"', in: Prinz zu Waldeck und Pyrmont et al. (eds.), Patents and Technological Progress in a Globalized World, Liber Amicorum for Joseph Straus (2009), p. 652, at 653 et seq. and the references cited there.

${ }^{14}$ Lionel Bently \& Brad Sherman, Intellectual Property, 2 ed. (Oxford University Press: Oxford 2004), at 5, 929; Alfredo Illardi \& Michael Blakeney, International Encyclopaedia of Intellectual Property Rights, (Oxford University Press: Oxford 2004), at 3; Paul Katzenberger \& Annette Kur, 'TRIPS and Intellectual Property', in Karl-Friedrich Beier \& Gerhard Schricker (eds.). From GATT to TRIPS, IIC Studies Vol.18 (Weinheim: New York 1996), p. 5; Christopher Arup, 'The New World Trade Organisation Agreements' (Cambridge University Press: Cambridge, 2000), p. 30; Annette Kur, 'A New Framework for Intellectual Property Rights - Horizontal Issues', (2004) 35 IIC 1, at 7.
} 
7. The national freedom to lay down the full range of those definitions and concepts is however partially superposed by obligations entered into in the international and the EU contexts. These limitations will be discussed in the following sub-sections.

\section{DEFINITION OF TRANSIT IN EU LAW AND SCOPE OF APPLICATION OF THE BMR}

8. The BMR is based on ex-Art. 133 EC (now Art. 207 TFEU) and is therefore part of the EU's common commercial policy. The common commercial policy is an exclusive competence of the EU, ${ }^{15}$ to the effect that any competence of the Member States in that field is excluded a priori and no rules interfering with the common commercial policy may be laid down by them. ${ }^{16}$

9. The BMR seeks to lay down rules pertaining to the border treatment of goods entering into and passing through the EU customs territory. The various modalities ${ }^{17}$ by which these goods enter or pass through the EU in the context of the EU Customs procedures form an essential part of the $\mathrm{BMR}^{18}$ and thus count among the EU's regulatory competences under the common commercial policy. Consequently, the Member States are not competent to alter or re-regulate the concept or definition of transit in, e.g., their national IP laws or under the territoriality principle.

10. The term transit is not defined in the BMR or in the EU Customs Code. ${ }^{19}$ Accordingly, uncertainty arises as to the exact scope of application of the BMR to each of the various possibilities of passage of goods through the EU. ${ }^{20}$ However, guidance as to the conditions under which the passage of goods may or may not be interfered with on the ground of alleged IP infringements may be derived from several sources.

a. Although neither the BMR nor the Customs Code define the term transit, the Customs Code makes use of that term, while the BMR does not. The BMR instead explicitly refers to acts of release for free circulation, export or re-

\footnotetext{
${ }^{15}$ Cf. now explicitly Art. 3 (1) (e) TFEU.

${ }^{16}$ For more, cf. e.g. Koen Lenaerts \& Piet van Nuffel, Constitutional Law of the European Union $\left(2^{\text {nd }}\right.$ ed. 2005), paras. 5-022 and 5-025 et seq.

${ }^{17}$ Cf. in particular Art. 4 (16) EU Customs Code, Council Regulation (EEC) No 2913/92, [1992] OJ L 302/1.

${ }^{18}$ Cf. Art. 1 BMR (fn. 1).

${ }^{19}$ Cf. fn. 18.
} 
export $^{21}$ and to goods entering or leaving the EU customs territory, ${ }^{22}$ which all stem from the Customs Code $^{23}$ and are used therein to refer to modalities of passage other than what the Code deals with under the heading of transit ${ }^{24}$ of non-EU goods. This indicates, firstly, that EU law does distinguish between transit and other forms of passage. Secondly, since the BMR does neither use the term transit nor cross-refer to provisions in the Customs Code dealing with the transit of non-EU goods specifically, the BMR apparently does not intend to apply to goods in transit.

b. This need for distinction between pure transit and other forms of passage through EU territory is reiterated by the jurisprudence of the ECJ. ${ }^{25}$ Under its case law, goods passing through the EU territory originating from third countries and en route to third-country destinations may not be interfered with on the grounds of alleged IP infringements unless the "goods are subject to the act of a third party while they are placed under the external transit procedure which necessarily entails their being put on the market in the Member State of transit." ${ }^{26}$ The ECJ thus assumes that pure transit, understood as passage not capable of having an effect on the internal market and the IP rights protected there, is off limits to interference on the grounds of alleged IP infringements, ${ }^{27}$ while forms of passage where the purity of the transit is tainted by "a risk that counterfeit goods placed under the external transit procedure may be fraudulently brought on to the [EU] market" ${ }^{28}$ may be held up. ${ }^{29}$

${ }^{20}$ Cf. already Grosse Ruse - Khan \& Jaeger (fn. 10) 510.

${ }^{21}$ Cf. Art. 1(a) BMR (fn. 1).

${ }^{22}$ Cf. Art. 1 (b) BMR (fn. 1).

${ }^{23}$ Cf. Art. 4 (15) and (16) EU Customs Code (fn. 17) in particular.

${ }^{24}$ Cf. Arts. 4 (16) (b), 54, 84 and 91 et seq. EU Customs Code (fn. 17) in particular.

${ }^{25}$ Cf. already Grosse Ruse - Khan \& Jaeger (fn. 10) 510 et seq.; Christian Heinze \& Stefan Heinze, ,Transit als Markenverletzung - Schlusswort des EuGH in der Entscheidung „Montex/Diesel“", GRUR 2007, 740, at 740 et seq.; Jeroen van Hezewijk, ,Montex and Rolex - Irreconcilable Differences? A Call for a Better Definition of Counterfeit Goods', (2008) 39 IIC 775, at 776 and 794.

${ }^{26}$ Case C-281/05 Montex [2006] ECR I-10881, para. 23.

${ }^{27}$ To that effect also Case C-281/05 Montex, [2006] ECR I-10881, para. 25.

${ }^{28}$ Case C-383/98 The Polo/Lauren Company [2000] ECR I-2519, para. 34.

${ }^{29}$ Cf. Case C-383/98 The Polo/Lauren Company [2000] ECR I-2519, para. 34; Case C-281/05 Montex [2006] ECR I-10881, para. 23 et seq. For a more detailed analysis, cf. Große Ruse - Khan \& Jaeger (fn. 10) 514 et seq. 
c. For these reasons also, there is no room for application of the so-called manufacturing fiction to acts of transit. The manufacturing fiction suggests that the question of infringement of an IP right is to be decided on the premise that the incriminated goods are manufactured in the country of transit. The Preamble to the BMR may in fact be read as containing a reference to the manufacturing fiction, ${ }^{30}$ to the effect that proceedings under the BMR could be initiated in relation to any good transiting through a country where it would infringe an IP right if it were manufactured there. Consequently, the applicability of the BMR to acts of transit is - even after Montex - still disputed in literature ${ }^{31}$ and likewise appears still unclear to national courts. ${ }^{32}$ An automatic presumption of infringement would be incompatible with the ECJ's differentiated approach to determining the infringement potential. Furthermore, however, a closer reading of the remaining provisions of the BMR also points towards a narrow reading of the preamble to exclude an application of the manufacturing fiction to acts of transit, in line with the ECJ's case law. Under the BMR, the primary aim of customs action against IP infringing goods is to prevent harm to manufacturers, traders and rightholders as well as consumers. ${ }^{33}$ To that end, the BMR stipulates that "[s]uch goods should [...] be kept off the market" 34 where those harmful effects may occur. Clearly, the market where such concerns are relevant for EU authorities can be the domestic market of the EU only. Consequently also, all of the measures defined in the BMR's Preamble as potentially justifying action under the BMR relate to acts where the goods have in some form entered the EU customs territory: Transhipment, release for free circula-

\footnotetext{
${ }^{30}$ Cf. BMR (fn 1) 8th indent Preamble: "Proceedings initiated to determine whether an intellectual property right has been infringed under national law will be conducted with reference to the criteria used to establish whether goods produced in that Member State infringe intellectual property rights" (emphasis added).

${ }^{31}$ For a recent overview, cf., e.g., Olivier Vrins, 'The real story of a fiction: transit after Montex under Regulation (EC) 1383/2003', (2010) J. Intellec. Prop. L \& Prac. 358, at 358 et seq. and 371.

${ }^{32} \mathrm{Cf}$. also two questions for preliminary ruling on this issue currently pending before the ECJ, Case C-446/09 Koninklijke Philips Electronic [2010] OJ C 24/29 (however relating to the old Customs Regulation No. 3295/94); Case C-446/09 Nokia Corporation [2010] OJ C 37/22 (relating to the BMR).

${ }^{33} \mathrm{Cf}$. BMR (fn 1) 2nd indent Preamble.

${ }^{34}$ BMR (fn 1) 2nd indent Preamble.
} 
tion in the EU, placing under a suspensive procedure and placing in a free zone or warehouse. 35

11. As a first preliminary result therefore, it can be said that EU law does contain definitions of the concept of transit, from which Member States IP laws and enforcement provisions may not diverge. While there are good grounds to assume that the BMR likewise embraces the general transit concept of EU law, the Preamble and operative provisions of the BMR are not fully clear in that respect and should be clarified accordingly. ${ }^{36}$ Suggestions for clarification will be made in the final section of this Statement.

\section{ENFORCEMENT CEILINGS UNDER INTERNATIONAL LAW}

12. Part III of the TRIPS Agreement contains 20 provisions on the enforcement of IP rights. It is the first comprehensive multilateral instrument setting out detailed obligations for domestic IP enforcement regimes. ${ }^{37}$ These TRIPS obligations to provide mechanisms for the "effective and appropriate",38 enforcement of IP rights are - as all other TRIPS obligations - primarily seen as international minimum standards for the protection of IP: They create a "floor" 39 consisting of a minimum level of protection which must be available in all WTO Members - without any apparent limitation as to the further extension of IP protection. This notion of minimum standards is a central feature in the long history of international IP protection whose development has primarily been a one-way route towards ever increasing levels of protection. ${ }^{40}$

\footnotetext{
${ }^{35}$ BMR (fn 1) 3rd indent Preamble.

${ }^{36}$ Similarly Marius Schneider, 'Guest Editorial: Counterfeiting counter-fight', Journal of Intellectual Property Law \& Practice 2010, 285, 285; Vrins (fn. 31) 371.

${ }^{37}$ In the two major international IP regimes prior to TRIPS, enforcement obligations where of general nature or limited to the issue of seizures - see Art.16 of the Berne Convention and Artt. 9, 10 and 10ter(1) of the Paris Convention. Compare also Daniel Gervais, The TRIPS Agreement - Drafting History and Analysis ( $3^{\text {rd }}$ ed. 2008), at 2.352

${ }^{38}$ See the Preamble of TRIPS, at (b).

39 Anthony Taubmann, 'Rethinking TRIPS: Adequate Remuneration for Non-Voluntary Patent Licensing', (2008) 11 JIEL 927, at 944.

40 Once rights have been inscribed into the text of an IP convention, "they basically become sacrosanct for now and the future." Revision conferences (with only a few remarkable exceptions of the Revision of the Berne Convention 1971 where an Annex addresses the option for developing countries to grant compulsory licenses mainly for translation purposes and the proposed amendment of the TRIPS Agreement in the course of the Doha process; see General Council, Decision of 6 December
} 
13. However, some provisions in existing treaty law from the Berne and Paris Convention as well as the TRIPS Agreement may function as a door-opener for binding limitations or "ceilings" Art.1(1) $2^{\text {nd }}$ sentence of TRIPS expressly allows WTO Members to grant more extensive protection than what is prescribed in the Agreement - but only "provided that such protection does not contravene the provisions of this Agreement". ${ }^{42}$ One justification for such a 'ceilings' function comes from the incorporation of TRIPS into the WTO multilateral trading system: As several TRIPS provisions indicate, not only the lack of, but also excessive (or abusive reliance on) IP protection can distort and create barriers to international trade. ${ }^{43}$ Especially for border measures against IP infringements, the strong link to global trade and the traditional WTO/GATT approach towards further trade liberalisation provide a rationale which explains binding language safeguarding the interests of traders. ${ }^{44}$ Against this background one can hardly sustain the position of the EU Commission, as expressed in the Consultation Paper to the BMR Review, which conceives TRIPS solely "as an agreement of minima". ${ }^{45}$ A ceilings approach finds further support in the recent requests for consulta-

2005, (WT/L/641) 8 December 2005)) have regularly served the purpose of further strengthening the position of right holders; hardly ever was an effort undertaken to question or curtail incumbent rules.; see Annette Kur \& Henning Grosse Ruse - Khan, 'Enough is Enough - The Notion of Binding Ceilings in International Intellectual Property Protection', Max Planck Papers on Intellectual Property, Competition \& Tax Law, Research Paper No.09-01; online available at http://ssrn.com/abstract=1326429 (accessed 3 March 2009).

${ }^{41}$ For a general analysis of this concept in international IP law see Kur \& Grosse Ruse - Khan, ibid.

${ }^{42}$ In full, Art.1(1) states: "Members shall give effect to the provisions of this Agreement. Members may, but shall not be obliged to, implement in their law more extensive protection than is required by this Agreement, provided that such protection does not contravene the provisions of this Agreement. Members shall be free to determine the appropriate method of implementing the provisions of this Agreement within their own legal system and practice" (emphasis added).

${ }^{43}$ See the TRIPS Preamble (emphasising the need to "ensure that measures and procedures to enforce intellectual property rights do not themselves become barriers to legitimate trade"), Art. 41 (1) TRIPS (regarding IP enforcement procedures) and Art.8 (2), 40 (1) TRIPS (on abuses of IP protection and anti-competitive licensing practices); compare also Correa, Trade Related Aspects of Intellectual Property Rights - A Commentary on the TRIPS Agreement (Oxford: Oxford University Press, 2007), at 25; ICTSD \& UNCTAD, Resource Book on TRIPS and Development: An authoritative and practical guide to the TRIPS Agreement (2005), at 575 (an earlier version of this publication is online available at www.iprsonline.org/unctadictsd/ResourceBookIndex.htm) and $K$ Elfring, in $J$ Busche \& $P$-T Stoll (eds), TRIPs - Internationales und Europäisches Recht Geistigen Eigentums, at 84.

${ }^{44}$ Compare Gervais (fn. 37) para. 2.414 who describes Artt. 51-60 TRIPS on border measures as the most "trade related" section of the TRIPS Agreement.

${ }^{45}$ See Consultation Paper, at 3. 
tions by India and Brazil under the WTO dispute settlement system. ${ }^{46}$ Concerning the seizure of generic drugs in transit discussed in section I above, these requests allege inconsistency (inter alia) of the BMR not only on the basis of the freedom of transit clause in Art. V of the General Agreement on Tariffs and Trade (GATT), but also with several TRIPS provisions which are understood as constraining the ability of WTO Members to introduce additional IP protection and enforcement measures in their national laws. ${ }^{47}$

14. In order to review the consistency of the TRIPS-plus elements of the BMR with TRIPS, one therefore needs to assess which form of additional IP protection has the potential to "contravene" TRIPS. ${ }^{48}$ Without excluding other arguments for findings of contravention, ${ }^{49}$ instances where this qualification of Art. 1(1) TRIPS applies are most likely in cases where one can point to conflicts with a mandatory TRIPS provision instead of an optional one. However, mandatory rules in the area of exceptions and limitations to IP protection are rare in international IP law ${ }^{50}$ where most take the form of optional provisions which allow a country to adopt a specific exception in its national IP regime. In relation to the TRIPS provisions on IP enforcement though, things are different: Several provisions contain binding language which set out general principles upholding procedural guarantees for the defendant or preventing the creation of trade barriers as well as specific obligations limiting enforcement measures. $^{51}$

\footnotetext{
${ }^{46}$ See WTO, European Union and a Member State - Seizure of Generic Drugs (EC - Seizure of Generics), Request for Consultations by Brazil (WT/DS409/1, IP/D/29, G/L/922) and by India (WT/DS409/1, IP/D/28, G/L/921), 19 May 2010

${ }^{47}$ The requests list inter alia inconsistencies with Artt. 1 (1), 2, 28, 31, 41 (1), 41 (2), 51, 52, 53 (1), 53 (2), 54, 55, and 59 TRIPS some of which will also be analysed further below. For a more comprehensive analysis see Grosse Ruse - Khan \& Jaeger (fn. 10) passim.

${ }^{48}$ For a more detailed analysis of this term see Kur \& Große Ruse - Khan (fn. 40) passim.

${ }^{49}$ See in particular the idea expressed in ICTSD \& UNCTAD (fn. 43) at 24 that pressure to accept TRIPS-plus standards in FTA negotiations might contravene the object and purpose of the WTO Agreement and TRIPS to provide a secure framework for the conduct of international trade relations.

${ }^{50}$ For an useful overview see Appendix B to Bernd Hugenholtz \& Ruth Okediji, Conceiving an International Instrument on Limitations and Exceptions to Copyright, Final Report 6 March 2008, online available at http://www.ivir.nl/publicaties/hugenholtz/finalreport2008.pdf (visited on 25 March 2008).

${ }^{51}$ See especially Artt .41 (1)-(4), $422^{\text {nd }}$ sentence, 43 (2), $463^{\text {rd }}$ sentence, 47,48 (1), 50 (3), (4), (6) TRIPS.
} 
15. The "Special Requirements Related to Border Measures" in Artt. 51-60 TRIPS begin by setting out the general obligation to adopt procedures, "to enable a right holder, who has valid grounds for suspecting that the importation of counterfeit trademark or pirated copyright goods may take place, to lodge an application in writing with competent authorities, administrative or judicial, for the suspension by the customs authorities of the release into free circulation of such goods. ${ }^{~} 52$ In line with the general 'ceilings' approach in Art. 1(1) $2^{\text {nd }}$ sentence, Art. $512^{\text {nd }}$ sentence then permits WTO Members to extend border measures to "goods which involve other infringements of intellectual property rights, provided that the requirements of this Section are met." It hence allows TRIPS-plus border enforcement measures applicable to, for example, alleged patent-infringing goods only if all requirements of Art. 52-60 are complied with. ${ }^{53}$ The WTO Panel in the recent China - IP Enforcement dispute $^{54}$ explicitly confirmed this when distinguishing the optional extension of border measures to goods involving other forms of IP infringements from extensions covering the exportation of goods under the $3^{\text {rd }}$ sentence of Art. 51 which merely requires "corresponding procedures". 55

16. The BMR extends IP protection beyond the minimum standards under Artt. 51-60 TRIPS in two directions: It applies to (1) goods involving IP infringements other than trademark counterfeits or copyright piracy ${ }^{56}$; and (2) to goods in transit. As to the first TRIPS-plus element, Art.51 $2^{\text {nd }}$ sentence explicitly demands that any such extension must meet the requirements of Artt.51-60 TRIPS. ${ }^{57}$ Secondly, extending border measures to goods in transit is addressed in fn.13 to Art.51 TRIPS which

\footnotetext{
${ }^{52}$ Art.51 $1^{\text {st }}$ sentence TRIPS (footnotes - inter alia defining counterfeit trademark and pirated copyright goods - omitted); these procedures must itself be consistent with the further requirements set out in Artt. 52-60.

${ }^{53}$ See also $S$ Vander, in J Busche \& P-T Stoll (fn.43), at 667.

${ }^{54}$ China - Measures Affecting the Protection and Enforcement of Intellectual Property Rights, Panel Report (WT/DS3262/R), 26 January 2009, especially paras. 7.396-7.674.

${ }^{55}$ The Panel (fn. 54) stated in para. 7.223 of its report: "The second sentence includes an express condition that applies where Members provide border measures for other infringements of intellectual property rights, namely 'provided that the requirements of this Section are met'." Based on the different language used in the third sentence, the Panel concluded that there is no obligation to comply with the requirements of Artt. 51-60 if a country extends border measures to goods destined for exportation (see para.7.224).

${ }^{56}$ As defined in fn.14 to Art. 51 TRIPS.
} 
states: "It is understood that there shall be no obligation to apply such procedures to (...) goods in transit." While under a plausible e contrario argument the EU hence may extend its border regime to goods in transit, ${ }^{58}$ this extension remains subject to the requirements in Artt.51-60 as far as goods involving other IP infringements are concerned. ${ }^{59}$ The BMR mandated border measures based on alleged patent infringements and applied to transiting consignments of generic medication from India destined for other developing countries hence must meet all requirements set out in the TRIPS provisions on border measures.

17. On the basis of the information available,$^{60}$ the most relevant constraint placed upon the custom seizures of generics in transit is set out in the $1^{\text {st }}$ sentence of Art. 52 TRIPS: Right holders initiating the procedures under Art. 51 TRIPS "shall be required to provide adequate evidence to satisfy the competent authorities that, under the laws of the country of importation, there is prima facie an infringement of the right holder's intellectual property right". When applying the BMR to the transit cases at issue here, EU authorities hence must demand adequate evidence for a prima facie IP infringement - based on the law of the country of importation. This follows not only from the underlying principle of territoriality, ${ }^{61}$ but finds further support in fn.14 to Art. 51 TRIPS which also refers to the law of the importing country to determine goods as containing counterfeit trademarks or copyright piracy. ${ }^{62}$ However, the detention/seizure of generics under the BMR has always been based

\footnotetext{
${ }^{57}$ See China - IP Enforcement (fn. 54), at para. 7.223

${ }^{58}$ The argument that Art. $512^{\text {nd }}$ and $3^{\text {rd }}$ sentence provides for a closed list of TRIPS-plus extensions is not convincing in light of fn.13 which implies that there is an option to foresee border measures for goods in transit; compare Correa (fn. 43), at 441.

${ }^{59}$ The fact that "goods in transit" as such are not explicitly subjected to the further conditions of Artt. 51-60 cannot be interpreted as "overriding" the consistency requirement of Art. $512^{\text {nd }}$ sentence. As far as the specific TRIPS provisions on border measures do not contain lex specialis (such as Art.51 $2^{\text {nd }}$ and $3^{\text {rd }}$ sentence), the general rule of Art. 1(1) $2^{\text {nd }}$ sentence TRIPS applies under which any TRIPS-plus extension must not contravene TRIPS provisions.

${ }^{60}$ Given the limited - and sometimes contrary - information available on the EU transit seizures, this section refrains from examining whether other BMR provisions which have been identified as potentially inconsistent with TRIPS (e.g. the simplified destruction procedure, the lack of any security requirement in favour of the goods' owner or any absence of liability for ex officio actions support further findings that the EU measures are violating WTO law.

${ }^{61}$ Gervais (fn. 37), at 2.420.

${ }^{62}$ See Correa (fn. 43), at 441.
} 
on the domestic IP law of the EU Member State through which these goods transit. ${ }^{63}$ Applying the law of the transit country for judging IP infringements, these measures thus are only consistent with Art. $521^{\text {st }}$ sentence TRIPS if the term "country of importation" under Art. 52 TRIPS includes transit countries.

18. While the ordinary, dictionary meaning of the term importation may be argued to include transiting goods, ${ }^{64}$ several TRIPS and GATT provisions may point to a more specific contextual understanding in our case: First of all, fn.13 to Art. 51 TRIPS explicitly distinguishes between certain imports and goods in transit. This distinction implies that the two are different and hence offers good arguments for a contextual interpretation of "laws of the country of importation" as only referring to the country of final destination. Other TRIPS provisions using variations of the term support this; ${ }^{65}$ while again others are less conclusive. ${ }^{66}$ Additional relevant context can be derived from Art. 41(1) TRIPS (obliging WTO Members to apply IP enforcement measures "as to avoid the creation of barriers to legitimate trade") and Art. V (2) GATT (demanding "freedom of transit through the territory of each contracting party"). ${ }^{67}$

${ }^{63}$ See Art.2(1)(c)(i) BMR (fn. 1) which defines infringing goods inter alia as "goods which, in the Member State in which the application for customs action is made, infringe: (i) a patent under that Member State's law"; compare further the statements of Brazil, India and the EC; The General Council Statements of India and Brazil (as well as an initial response by the EC) are online available at http://www.ip-watch.org/weblog/2009/02/03/concern-erupts-over-wto-system-and-medicines-

shipments-trips-talks-rekindling/ (accessed 22 April 2009); see further the TRIPS Council statements of India and of Brazil - both under Agenda Item M (Other Business), Public Health Dimension of the TRIPS Agreement, online available at http://www.ip-watch.org/weblog/2009/03/05/concernscontinue-over-genericsdrug-seizures-as-legality-debates-begin/ (accessed 18 April 2009).

${ }^{64}$ For a more detailed analysis Grosse Ruse - Khan/Jaeger (fn. 10) 532 et seq.

${ }^{65}$ See Art. 44 and 50(1) TRIPS which refer to imported goods (destined or likely to) entering into the channels of commerce.

${ }^{66}$ See Art. 28 (a) and Art. 36 which both include importing within the scope of exclusivity; further Artt. 53 (2), 54, 55, 56 and 60 may contain relevant context. Finally, fn. 14 to Art.51 uses the same term ("law of the country of importation") as determining the relevant law for judging counterfeit trademarks and copyright piracy.

${ }^{67}$ Since the Agreement Establishing the World Trade Organisation (WTO Agreement) incorporates both GATT and TRIPS as its annexes, Art. 31(2) VCLT - stating that relevant interpretative context comprises inter alia the annexes of a treaty - allows to use GATT provisions as relevant context for TRIPS interpretation. At the same time, the internal consistency of the WTO as a legal system demands a interpretation which aims for mutual coherence and balance between the interests pursued in the different WTO Agreements (see Argentina - Footwear, Appellate Body Report (WT/DS121/AB/R), 14 December 1999, at para.81; where the WTO Appellate Body held - in relation to GATT and the Agreement on Safeguards - that the provisions of both agreements are all pro- 
19. As discussed above, the WTO/TRIPS rationale aiming for IP protection to facilitate and not inhibit international trade is particularly relevant in the enforcement chapter of TRIPS and may explain the existence of several limits (or ceilings) imposed on TRIPS-plus protection. The first paragraph of the TRIPS preamble confirms this objective. ${ }^{68}$ Given the importance Art. 31 of the Vienna Convention on the Law of Treaties (VCLT) attaches to the object and purpose of the treaty, this ratio may require an understanding of the term "country of importation" which minimises the ability of TRIPS-plus border measures to interfere with international trade. ${ }^{69}$ Arguably, the objectives and principles embodied in Art. 7 (calling for IP protection and enforcement to be "conducive to social and economic welfare") and Art. 8 TRIPS (allowing TRIPS consistent measures to protect public health) can further support such an interpretation. All WTO Members, including the EU, have further emphasised the importance of these provisions for the interpretation of all TRIPS provisions in para. 5 a) of the Doha Declaration on TRIPS and Public Health. ${ }^{70}$

20. In paragraph 4 of the Doha Declaration, WTO Members "agree that the TRIPS Agreement does not and should not prevent Members from taking measures to protect public health. Accordingly, while reiterating our commitment to the TRIPS Agreement, we affirm that the Agreement can and should be interpreted and implemented in a manner supportive of WTO Members' right to protect public health and, in particular, to promote access to medicines for all." ${ }^{, 71}$ Here the public health di-

visions of one treaty, the WTO Agreement, are hence an integral part of the body of WTO law and must be considered in conjunction).

${ }^{68}$ In that paragraph WTO Members place as first intention of TRIPS the desire "to reduce distortions and impediments to international trade, and taking into account the need to promote effective and adequate protection of intellectual property rights, and to ensure that measures and procedures to enforce intellectual property rights do not themselves become barriers to legitimate trade".

${ }^{69}$ Such a result must not be seen as effectively invalidating the ability to extend border measures to goods in transit. Whenever this is combined with extending them to goods involving other IP infringements, Art.51 $2^{\text {nd }}$ sentence explicitly qualifies this ability with the requirement of meeting the conditions set out in Artt. 51-60. In this regard, Art. 51 contains a deliberate limitation relevant for the overall scope of how WTO Members can extend border measures beyond TRIPS.

${ }^{70}$ See Ministerial Conference, Doha Declaration on the TRIPS Agreement and Public Health (WT/MIN(01)/DEC/2), 20 November 2001 which emphasises in para.5 a) as one as the key flexibilities under TRIPS that "in applying the customary rules of interpretation of public international law, each provision of the TRIPS Agreement shall be read in the light of the object and purpose of the Agreement as expressed, in particular, in its objectives and principles."

${ }^{71}$ See Ministerial Conference (fn. 70). 
mension of the TRIPS Agreement and the Doha Declaration on TRIPS and Public Health can exercise an influence on whether the rather open term "country of importation" should encompass transit countries: A wide understanding allows for TRIPSplus measures which, as applied in by EU Member States, can frustrate other WTO Members' ability to promote social welfare, protect public health and facilitate access to medicines.

21. Further, an effective implementation of the WTO "paragraph six mechanism, ${ }^{, 72}$ could also be at risk whenever medication produced under a compulsory licence for export to a country with insufficient manufacturing capacity transits through EU ports. ${ }^{73}$ Even in this scenario the BMR seems to offer no safeguards against seizure solely based on transit: As soon as such medication is patent protected in one of the EU Member States, it may be subject to seizure and destruction. ${ }^{74}$ However by seizing drugs produced under the paragraph six mechanism, the EU would directly contradict the efforts undertaken by the WTO and its Members to promote access to medicines in these cases. Hence, seizures of goods in transit may even effectively invalidate the supply of drugs under the "paragraph six mechanism" to countries with no sufficient pharmaceutical manufacturing capacities. The TRIPS objectives and principles, identified in para. 5(a) of the Doha Declaration as central for the interpretation of all of TRIPS provisions, however, mandate an understanding of TRIPS which is supportive to public health measures and does not frustrate them. One may hence conclude that various contextual and functional arguments call for a narrow interpretation of the term "country of importation" which excludes transit countries.

22. This applies in particular whenever there is no substantiated threat of trade diversion onto the market of the "transit" country. If in turn such a threat does exist, the situa-

\footnotetext{
72 See General Council, Decision of 30 August 2003, (WT/L/S40 and Corr. I) 1 September 2003; and Decision of 6 December 2005, (WT/L/641) 8 December 2005). The 'paragraph six mechanism' (so called due to its original mandate in para.6 of the Doha Declaration) which this General Council decision implements allows exports of medicines produced under a compulsory license into countries with insufficient manufacturing capacities.

${ }^{73}$ Statement by India (fn. 63), and the Consultation request by India (fn. 46).

${ }^{74}$ Cf. Frederick Abbott, 'Worst Fears Realised; The Dutch Confiscation of Medicines Bound from India to Brazil', Vol.13 Bridges No.1 (March 2009), online at http://ictsd.net/i/news/bridges/44192/ (accessed 19 April 2009).
} 
tion is equivalent to that of importation and not of mere transit. It hence is convincing to argue that applying the law of the country onto whose market the goods may be diverted is an application of the law of the country of importation and thus consistent with Art. 52 TRIPS. However, by allowing (or even mandating) the application of the law of the transit country also in cases where there is no real threat of trade diversion onto the domestic market of the transit country, ${ }^{75}$ the BMR appears inconsistent with Art. 52 TRIPS.

23. As a second preliminary result therefore, the TRIPS obligations pertaining to border measures in the national laws of WTO Members (and hence relevant for the BMR) impose restrictions on the ability to adopt measures which serve as a barrier to legitimate trade and which undermine the ability of WTO members to protect public health and access to medicines. The existing scope of the BMR - covering goods in transit as well as patent infringements - has significant potential to be applied and implemented by custom authorities in a way which creates trade barriers and undermines public health policies abroad. Such an application is inconsistent with the enforcement obligations under the TRIPS Agreement.

\section{BALANCING OF INTERESTS AND SCOPE OF APPLICATION OF THE BMR}

24. Notwithstanding that other interests may play a role in the hold-up of goods not destined for the EU territory by the means provided under the BMR depending on the exact circumstances (like the protection of health, consumers, legal certainty etc.), an interference with goods in transit will typically see the interests of the rightholder in forestalling infringements on the one hand and of the manufacturers and traders of the incriminated goods as well as states and potential non-state stakeholders (like the WHO) in securing free trade on the other hand juxtaposed. Depending on factors such as, in particular, the degree of clarity of the infringement (e.g. outright copying as opposed to mere risk of confusion in the trademark context) and

\footnotetext{
${ }^{75}$ For cases where such a threat is proven one could argue that the goods are in effect not merely in transit and that hence it is not the law of the transit country, but that of the country of (de facto) importation which is applied.
} 
the illicit character of the commercial activity, also from the point of view of the country of destination, the interests of one or the other side deserve more protection.

25. This means that the concept of transit and the principle of non-interference in transit under EU law and TRIPS respectively, as just laid out above, should not be fully dissociated from the circumstances of the case.

a. In cases where the infringement as well as the intention to infringe, copy or counterfeit are clear and beyond doubt, manufacturers or traders should not be able to rely on the benefits of the transit procedure to carry on manifestly illicit activities. Anything else would amount to allowing misuse of the transit procedure.

b. Where, on the other hand, the existence of an infringement is uncertain or where the goods could legitimately marketed in the country of destination, the interest in a free flow of goods should prevail over private party interests in enforcing a particular IP right.

c. Where the final destination of a consignment and, therefore, the possibility of legal marketing at that final destination are unclear, it appears that failure to provide full clarity about the modalities of transit and the port of final destination would lie in the responsibility of the person responsible for shipment and thus justify interference.

26. As a third preliminary result, therefore, the BMR, when providing for respect of goods in transit in line with EU law and TRIPS as just discussed, should also embrace safeguards against misuse of the transit procedure in individual, clearly defined cases.

\section{STANDARD OF PROOF REQUIRED FOR ACTION UNDER THE BMR}

27. Where the BMR is amended to adopt a differentiated concept of transit in line with the provisions of EU law and TRIPS as well as safeguards against a misuse of the transit procedure in cases of clear and intentional infringement as outlined above, the question arises as to the documentation and proof required from the applicant under 
the BMR to establish the existence of a risk of diversion of the goods or of a misuse of the transit procedure.

28. Here again, the chosen standard must reflect a balancing exercise: It should not be excessively high so as to render enforcement impossible or ineffective in practice or to entail excessive efforts for the applicant, but it should also not have the effect of creating a vast gap between the tools of action handed to the applicant under the BMR as compared to what is subsequently enforceable before the national courts under their standards of proof. In other words, a sufficient degree of certainty of existence of an enforceable claim is required also for the border measures procedure. Anything else would open the BMR procedures to potential abuse to effectuate holdups without likelihood of subsequent court enforcement of the claim and thereby run counter to the principle of rule of law as enshrined in Art. 2 TEU.

29. Customs authorities must therefore be in the position to clearly and swiftly establish on a prima facie basis whether risk of diversion or an abuse of the transit procedure exists. Cases where the establishment of the infringement or of the risk of diversion require a complex assessment transcend the scope of action that customs authorities can carry out with a sufficient degree of legal certainty. In complex cases therefore, the aforementioned balancing must come out in favour of a free flow of goods. If the concerns of infringement of criminal activity or infringement are really grounded, these cases should be pursued in the jurisdictions of origin or destination, but not in transit jurisdictions.

30. What documentation may appropriately be demanded from an applicant for border measures will eventually have to be examined and determined in light of customs' experiences in dealing with alleged infringements. For the sole purpose of stating preliminary examples of what might be imagined here, the following might represent potentially appropriate documentation as a prerequisite for action by the competent authorities.

a. For action on grounds of a risk of diversion of goods to the EU: 
i. In line with the ECJ's case law, proof of "existence of a release for free circulation [...] or of another act necessarily entailing their being put on the market in such a Member State., 76

ii. That standard might be fulfilled, for example, by showing that for essentially similar dispatchments or for the same consignor/consignee, diversion has taken place in the past, or that the addresses of destination or of origin are fake.

b. For action on grounds of an abuse of the transit procedure for conduct of a manifestly illicit activity:

i. Proof that the goods in question are in clear infringement of the IP right both in the transit country and also in the country of destination, e.g. in the case of trademarks that the signs are identical or essentially indistinguishable. This could be established by furnishing samples and representations to the customs authorities beforehand or upon infringement.

ii. In addition, unambiguous proof of the existence and validity of the IP right in both one of the countries of the internal market and the country of destination. While registration documents will typically suffice here, other appropriate means of proof could be identified in line with customs authorities' experience.

c. The burden of proof in the above situations should, as has already been indicated, rest entirely with the applicant.

d. In line with the above balancing of interests however, the absence of any information about the final port of destination should work to the benefit of the applicant and justify a holdup until that destination is sufficiently and credibly clarified by the other party.

31. Application of the above standard of proof will typically result in an exclusion of alleged infringements of patents, utility models or plant breeders' rights by goods in transit from the scope of application of the BMR. Further, that standard also accepts

\footnotetext{
${ }^{76}$ Case C-281/05 Montex [2006] ECR I-10881, para. 26.
} 
that some cases of infringement or illicit activity may escape from the scope of action of the rightholders and authorities. Likewise, it is accepted that some dispatchments may be held up unjustifiably on suspicion of diversion, because they look similar to dispatchments that were diverted in the past. All of this is however accepted as a result of the aforementioned balancing exercise and with a view to ensuring a fair balancing of the interests involved in the majority of cases.

\section{DIFFERENTIATION ACCORDING TO IP RIGHTS}

32. It has been argued above that in line with the relevant legal provisions, border measures should be made available in relation to goods in transit where there is a manifest risk that the goods in question may leak into the market of a Member State where they infringe an existing IP right or in the case of manifestly illicit activities. This approach should be taken across the board, without differentiating as to the type of right at issue.

33. If however that suggestion is not followed in the course of reform of the BMR, it should at least be made sure that the availability of border measures remains restricted to IP rights where customs authorities are effectively in the position to verify the infringement in an uncomplicated and reliable manner. This may entail a need for differentiation in the scope of application of the BMR according to IP rights and the nature of those rights.

34. IP rights which involve complicated technical or scientific assessments can clearly be handled by customs authorities with a larger degree of certainty regarding the existence of an infringement. Complex technical and scientific assessments are typically involved in relation to patents and similar rights (e.g. utility models, plant varieties). ${ }^{77}$ By contrast as concerns trademarks ${ }^{78}$ and similar rights (e.g. designs) and

\footnotetext{
${ }^{77}$ Similarly., e.g., von Mühlendahl \& Stauder, (fn. 13) 659 et seq. and 669 et seq.; Mario Leitzen, ,Innergemeinschaftlicher Transit, Markenverletzung und Produktpiraterie - Zugleich Anmerkung zu BGH „Diesel“ und EuGH „Class International/Colgate-Palmolive“”, (2006) GRUR 89, at 96; Iouri Kobianko, ,Durchfuhr als Patentverletzungshandlung? - Zugleich Anmerkung zum Urteil des LG Hamburg vom 2. April 2004', (2004) GRUR Int. 832, at 836; Dieter Stauder, Patentverletzung im grenzüberschreitenden Wirtschaftsverkehr (1975), p. 151.
} 
for copyrights, ${ }^{79}$ customs authorities may more easily assess the infringing potential on their own by a simple prima facie comparison of samples. This differentiation is also largely supported in literature. ${ }^{80}$

35. Accordingly, in the event that the solution advocated here for a differentiated definition of transit and the exclusion of pure forms of transit from the BMR is not followed, it may become necessary to exclude from the scope of application of the BMR border measures against goods allegedly infringing patents and similar technical rights, unless the goods in question are destined for or threaten to end up in a Member State where they infringe an existing IP right. This should however be analysed further in light of concrete customs experience in dealing with infringements of such technical IP rights.

\section{PROCEDURAL RIGHTS}

36. The BMR provides a legal basis for border measures already upon a prima facie suspicion of an infringement of virtually any type of IP right at a level which is set significantly above the standard of the TRIPS Agreement. ${ }^{81}$ The expansion of the scope of rights under TRIPS in the BMR is however currently one-sided insofar as the rights of defence for the owners of the goods in question were not expanded ac-

\footnotetext{
${ }^{78}$ Cf. Reinhard Ingerl \& Christian Rohnke, Markengesetz (2003), § 14, para. 200 and the literature cited there; Leitzen (n. 77), at 96; different Joachim Starck, ,Markenmäßiger Gebrauch - Besondere Voraussetzung für die Annahme einer Markenverletzung?', (1996) GRUR 688, at 693; Heinze \& Heinze, (fn. 26), at 748.

${ }^{79}$ Cf., e.g, Thorsten Braun \& Alexandra Heise, ,Die Grenzbeschlagnahme illegaler Tonträger in Fällen des Transits - Zugleich Anmerkung zum Urteil des EuGH vom 6. 4. 2000 Rs. C-383/98 Polo/Lauren', (2001) GRUR Int 28, at 30 et seq., although the authors advocate the adoption of a wider approach.

${ }^{80}$ Cf., e.g., Starck (fn. 78), at 693; Kobianko (fn. 77), at 835 et seq.; Leitzen (fn. 77), at 95 et seq.; Stauder (fn. 77), at 151; von Mühlendahl \& Stauder (fn. 13) at 659 et seq. and 669 et seq.; FriedrichKarl Beier, 'Territoriality of Trademark Law and International Trade', (1970) 1 IIC 48, at 66; Ilanah Simon, 'How Does „Essential Function“ Doctrine Drive European Trade Mark Law? - What Is the Essential Function of a Trade Mark?', (2005) 36 IIC, 402, at 403; different Grn Karan, 'Recent Developments in Turkey on Combating Counterfeiting by the Seizure of Counterfeit Goods in Transit or Those Placed in Free Zones as Compared with European Practice', (2006) 37 IIC 670, at 679 et seq.; Paul Geller, 'Internationales Immaterialgüterrecht, Kollisionsrecht und gerichtliche Sanktionen im Internet', (2000) GRUR Int. 659, at 663.

${ }^{81}$ For more detail Große Ruse - Khan \& Jaeger (fn. 10) at 507.
} 
cordingly. Here, a number of amendments are called for to improve legal protection for parties subject to measures under the BMR.

a. Unlike TRIPS, the BMR provides for a simplified procedure "which enables customs authorities to have such goods abandoned for destruction under customs control, without there being any need to determine whether an intellectual property right has been infringed under national law." 82 Recourse to this simplified procedure is possible if the owner of the goods does not oppose the destruction within a prescribed time limit. ${ }^{83}$ The BMR should be amended to make proof of the infringement a precondition for the suspensive measures under the simplified procedure for the destruction of the goods concerned.

b. The BMR currently accords the owners of the goods certain rights to be informed $^{84}$ of the measures taken and to inspect ${ }^{85}$ the goods concerned, but a right of objection is only contained in the BMR in relation to a possible destruction of the goods. ${ }^{86}$ In particular, the BMR does currently not afford any direct procedural remedies against the measures taken, like, for example, a right to be heard already before the customs authorities. Any such procedural guarantees are reserved for the post-customs phase, i.e. appeals procedures and civil litigation. The BMR should be amended here to sketch out at least the conditions and time-limits for appeals against measures taken by the customs authorities.

c. As regards the forwarding of information to the rightholder, the wording of the BMR in fact even seems to stay behind some defence rights laid down in TRIPS: TRIPS stipulates that the names and addresses of the consignor of the lot of goods in question and information on the quantities involved may only be forwarded to the rightholder where "a positive determination of the merits

\footnotetext{
${ }^{82}$ Art. 11(1) BMR (fn. 1). In Art. 59 TRIPS in turn demands that destruction or disposal of infringing goods must be "in accordance with the principles set out in Article 46". This provision does not only limit authority to destroy/dispose to "goods that [the judicial authorities] have found to be infringing", but also requires that "the need for proportionality between the seriousness of the infringement and the remedies ordered as well as the interests of third parties shall be taken into account."

${ }^{83}$ Art. 11(1) BMR (fn. 1).

${ }^{84}$ Cf. Artt. 4(1), 9(2) and 11(1) BMR (fn. 1).

${ }^{85}$ Cf. Art. 9(3) BMR (fn. 1).
} 
of the case ${ }^{\text {87 }}$ has been undertaken. The BMR instead obliges the customs authorities to forward this kind of information "if known" 88 upon request. The BMR should be amended to include details of precautions against the misuse of such information by the rightholder beyond the current stipulation of civil liability. ${ }^{89}$ In any case, it should be brought in line with any binding safeguard of the interests of traders which is foreseen in the TRIPS Agreement. As explained in detail in paragraphs 12-23 above, TRIPS qualifies the right to introduce additional IP protection by the requirement that such measures do not 'contravene' TRIPS.

d. The liability of the customs authorities is excluded under the BMR, unless such liability is recognized by the domestic law of the given Member State. This applies also where action was taken ex officio. ${ }^{90}$ Again, the TRIPS consistency of this provision appears questionable under Art. 58(c) TRIPS, which allows limitations of liability for ex officio actions only "where actions are taken or intended in good faith". The BMR should be amended to be brought in line with TRIPS in this respect.

e. Similarly, the inclusion of details in the BMR on the conditions for liability of the applicant, currently fully absent in the BMR, ${ }^{91}$ would be favourable from the point of view of legal certainty. It would also ensure common standards within the EU and so eliminate trade distortions regarding third country imports into the EU which may be caused by distinct standards in different Member States.

f) The obligation contained in Art.53:1 TRIPS to enable customs to make border measures conditional upon the provision of a security by the applicant does not appear to be fully implemented in the current version of the BMR. The BMR is satisfied with a declaration by the applicant accepting liability for his actions

${ }^{86}$ Cf. Art. 11(2) BMR (fn. 1).

${ }^{87}$ Art. 57 TRIPS.

${ }^{88}$ Art. 9(3) BMR (fn. 1).

${ }^{89}$ Cf. Art. 12 BMR (fn. 1).

${ }^{90}$ Cf. Art. 19(1) and (2) BMR (fn. 1).

${ }^{91}$ Cf. Art. 19(3) BMR (fn. 1). 
and agreeing to take over any costs associated with the border measures. ${ }^{92}$ As it may be questioned whether this amounts to a "security or equivalent assurance sufficient to protect the defendant (...) and to prevent abuse" under Art. 53:1 TRIPS, the BMR should be amended to require the applicant to provide a security deposit which covers at least the estimated market value of the goods in the country of destination.

37. The current limitations to the rights of defence may work to enhance the effectiveness and swiftness of border procedures, but they also invite rightholders to make extensive use of the mechanisms laid down while at the same time containing limited safeguards against potential misuses of those mechanisms. The seizures and even the mere temporary detention of generic drugs in transit provide concrete evidence of the BMRs potential for abuse. The current procedural imbalances and loopholes for abuse should accordingly be closed.

\section{SUMMARIZED POSITION}

38. In view of the foregoing, the Max Planck Institute for Intellectual Property, Competition and Tax Law proposes the following amendments to the definitions, scope and procedural provisions of the BMR.

39. The Preamble to the BMR should be clarified in line with the ECJ's case law as renouncing an applicability of the manufacturing fiction to genuine acts of transit.

40. The scope of the BMR should be narrowed to include any form of transit only if there is a substantiated threat of

a. either trade diversion onto any of the markets of the EU member states;

b. or of a misuse of the transit procedure for conduct of an illicit activity - judged both under the law of the transit country and the country of destination.

41. Art. 3 BMR should also be entitled "Exclusions from the Scope" to better highlight its function as summarizing exclusions from scope. Art. 3 BMR should then be remodelled to incorporate the following changes:

${ }^{92}$ Cf. Art. 6 (1) BMR (fn. 1). 
a. A clarification that 'genuine' acts of transit (i.e. those not entailing any substantiated threat of trade diversion or misuse) are not covered by the BMR should be included in Art. 3 BMR.

b. In the alternative, i.e. if acts of transit are not excluded from the scope of the BMR as suggested, the question arises as to whether the scope of application of the BMR should be reduced to IP rights and situations where the customs authorities can establish the existence of the infringement on a prima facie basis with sufficient certainty. This may therefore mean that infringements of technical IP rights like patents, utility models or plant breeders rights could not be enforced under the BMR. This question should be examined further in light of customs' experiences in dealing with such alleged infringements.

c. An exclusion from the scope should also apply to specific public health-related transits. Here, drugs shipped under recognised donor programmes or under the "paragraph six mechanism" should be a priori excluded from any customs action. Labelling or certification tools may be employed to safeguard against abuses. All international and foreign national health institutions and authorities could, by offering respective evidence, be allowed to register with custom authorities. After registration, transit shipments carrying a certificate and verifiable statement of origin, destination and public health use of the drugs should be exempted from any customs control regarding any alleged IP infringements.

42. Section 2 of the BMR, laying down the preconditions for applications for customs action, should be amended to clearly spell out the documentation required in applications relating to goods formally designated to be in transit through the EU. What documentation may appropriately be demanded from an applicant for border measures should be determined in the light of customs' experiences in dealing with alleged infringements. To state some examples of potentially appropriate documentation, action by the competent authorities could be made dependent upon proof that

a. for essentially similar dispatchments or for the same consignor/consignee, diversion has taken place in the past;

b. the addresses of destination or of origin are fake; 
c. the goods in question are in clear infringement, e.g. identical or essentially indistinguishable, of IP rights protected by registrations both in at least one jurisdiction of the EU as well as in the country of destination. To that end, samples, representations and proof of the existence and validity of the IP rights in all pertinent jurisdictions (e.g., but not only, through registration certificates) would have to be furnished to the authorities together with the application at latest.

d. Section 2 should clarify that the burden of proof for a risk of diversion or misuse rests entirely with the applicant.

e. Unclarity about the final port of destination might justify a hold-up until that destination is sufficiently and credibly clarified by the other party

43. In order to achieve TRIPS-conformity and a better balancing in terms of the procedural rights under the BMR, the following amendments should be included in the procedural provisions of the BMR:

a. Proof of the infringement should be made a precondition for the suspensive measures under the simplified procedure for the destruction of the goods concerned.

b. The conditions and deadlines for appeals against measures taken by the customs authorities should be defined.

c. Details of precautions against the misuse of such information by the rightholder beyond the current stipulation of civil liability should be included.

d. Liability for ex officio actions should be excluded only where those actions are taken or intended in good faith.

e. Conditions for liability of the applicant should be spelt out.

f. The applicant should be required to provide a TRIPS consistent security deposit or equivalent assurance sufficient to protect the defendant and to prevent abuse.

MUNICH, MAY 2010 